\title{
Article \\ Rainwater Harvesting for Irrigation of Tennis Courts: A Case Study
}

\author{
Carla Pimentel-Rodrigues ${ }^{1,2, *(\mathbb{D})}$ and Armando Silva-Afonso ${ }^{1,3}$ (D)
}

Citation: Pimentel-Rodrigues, C.;

Silva-Afonso, A. Rainwater

Harvesting for Irrigation of Tennis

Courts: A Case Study. Water 2022, 14

752. https://doi.org/10.3390/

w14050752

Academic Editor: Arturo Alvino

Received: 2 January 2022

Accepted: 23 February 2022

Published: 26 February 2022

Publisher's Note: MDPI stays neutral with regard to jurisdictional claims in published maps and institutional affiliations.

Copyright: (C) 2022 by the authors. Licensee MDPI, Basel, Switzerland. This article is an open access article distributed under the terms and conditions of the Creative Commons Attribution (CC BY) license (https:// creativecommons.org/licenses/by/ $4.0 /)$.
1 ANQIP_National Association for Quality in Buildings Services, 3810-193 Aveiro, Portugal; asilva.afonso@outlook.pt

2 ISCIA-Higher Institute of Information and Administration, 3810-488 Aveiro, Portugal

3 RISCO-Research Center for Risks and Sustainability in Construction, Department of Civil Engineering, University of Aveiro, 3810-193 Aveiro, Portugal

* Correspondence: anqip@anqip.pt; Tel.: +351-234-092-597

\begin{abstract}
It has become evident that, during this century, climate change will continue, affecting all regions of the planet. The expected impacts over the next few decades may differ from region to region, with some areas becoming humid and others drier. In regions such as the Mediterranean basin, the main expected impacts of climate change will be prolonged droughts and an increase in the intensity and frequency of heavy rains. Measures of mitigation and adaptation are particularly important in urban environments, where more than half of the population lives, and rainwater harvesting systems (RWHS) are considered to be a very suitable solution to these problems. However, the published studies have mainly focussed on buildings, with very limited references to the interest of its application in large urban infrastructure. Based on consumption and precipitation data, this article presents a study on the implementation of an RWHS in a large-scale sports infrastructure located in the city of Cascais (Portugal) intended for the practice of tennis, with 12 brick dust fields, some of them covered. The average annual consumption of potable water for watering the tennis courts is $5500 \mathrm{~m}^{3}$, and the results show that the RWHS can reduce this consumption by $>50 \%$, in addition to other expected benefits, such as the known effect of these systems in reducing flood peaks in the area.
\end{abstract}

Keywords: rainwater harvesting; climate change; water efficiency; tennis courts

\section{Introduction}

It has become evident that, during this century, climate change will continue, with an extent that will depend on the emission mitigation policies that are implemented [1]. By the end of this century, the global average temperature will rise by $2.6-4.8^{\circ} \mathrm{C}$ from its current value [2], and more frequent and intense extreme weather events will result in a higher incidence of floods and droughts around the planet $[3,4]$.

Variations in precipitation characteristics because of climate change are expected to differ from region to region on the planet, with some areas becoming humid and others drier, increasing precipitation in high latitude regions and decreasing it in most subtropical areas [5-8]. Regarding the European continent, southern and central Europe will face increasingly frequent heat waves and droughts. The Mediterranean area, in particular, is gradually becoming dry and, therefore, it is becoming even more vulnerable to droughts [9-11].

Regardless of the reduction in annual precipitation, an increase in the intensity and frequency of heavy rains is another important impact of expected climate change in the coming decades, and this trend will also affect the Mediterranean regions [12-17].

According to the United Nations, about $54 \%$ of the population on the planet currently lives in cities, but this percentage is expected to increase to $66 \%$ by 2050 . Therefore, the impact of climate change on cities will be very significant in the future and will drive measures to improve adaptation and greater resilience to more extreme weather conditions $[1,18]$. 
More frequent and intense winter rains could lead to exceptional flooding that would substantially impact urban areas [19-25]. Extreme precipitation events can cause, within urban areas, the overflow of interior water lines, affecting riverside areas, and can also cause flooding in non-marginal areas due to the lack of capacity of urban stormwater drainage systems, which generally have not been dimensioned for exceptional scenarios. The frequency with which this insufficiency of public stormwater drainage networks occurs can be further increased by using inadequate regulatory return periods, given the current reality of climate change, in the design of public systems. These situations can cause, among other consequences, the occurrence of excessive surface runoff, causing damage to urban infrastructure, eventually with greater impact after prolonged periods of drought.

It has been recognised that rainwater harvesting systems (RWHS) in buildings can be an important measure of adaptation to the urban environment, as they can contribute not only to the interception and storage of rainwater, significantly dampening flood peaks, but also for the conservation of potable water, as these systems allow the alternative use of rainwater for non-potable purposes $[7,26]$. It is important to note that the use of rainwater in cities can be considered not only in buildings but also in other infrastructure and urban equipment. This article presents a case study regarding the possibility of installing an RWHS in a large urban facility, the Estoril Tennis Club (ETC), intended for sports activities (tennis and paddle). This sports complex (Figures 1 and 2) is located in Portugal (Cascais) near the capital, Lisbon.

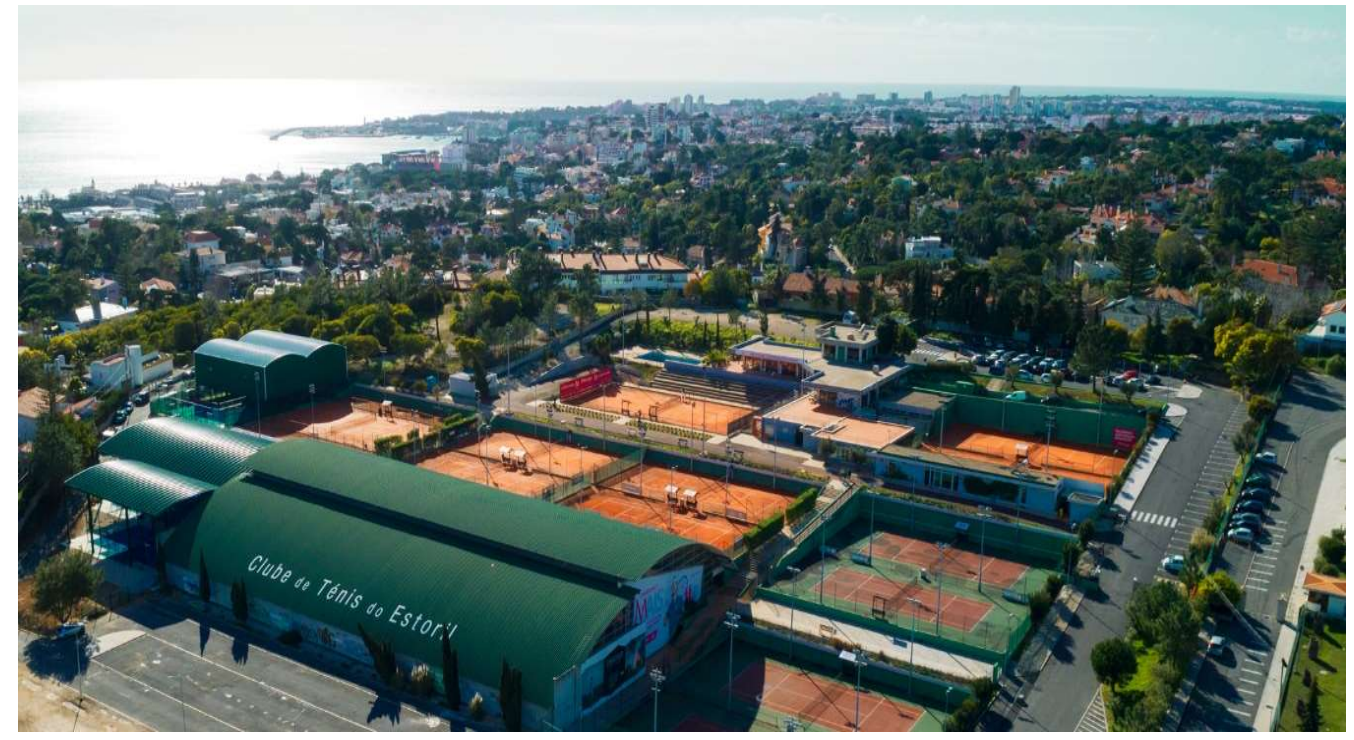

Figure 1. Aerial view of the Estoril Tennis Club (ETC).

It should be noted that Portugal is a Mediterranean country which, according to forecasts, will be one of the most affected by climate change and will suffer not only prolonged droughts, but also extreme rainfall events. Indeed, official forecasts indicate that, in the period of 2040-2070, an average annual temperature increase of $2-3{ }^{\circ} \mathrm{C}$ and an annual precipitation decrease of 20-25\% may occur in Portugal, despite the incidence of more frequent and extreme precipitation events, implying greater risks of flooding. Under these conditions, the use of RWHS in Portugal is an adaptative measure of great interest because it addresses both problems.

With regard to the installation of RWHS in large public sports facilities, there are some studies in Portugal and in other countries [27] that have shown, in general, the great interest and feasibility of these solutions. However, the studies carried out have focussed essentially on stadiums, without any known application in large infrastructure dedicated to tennis, such as in the present case study. 


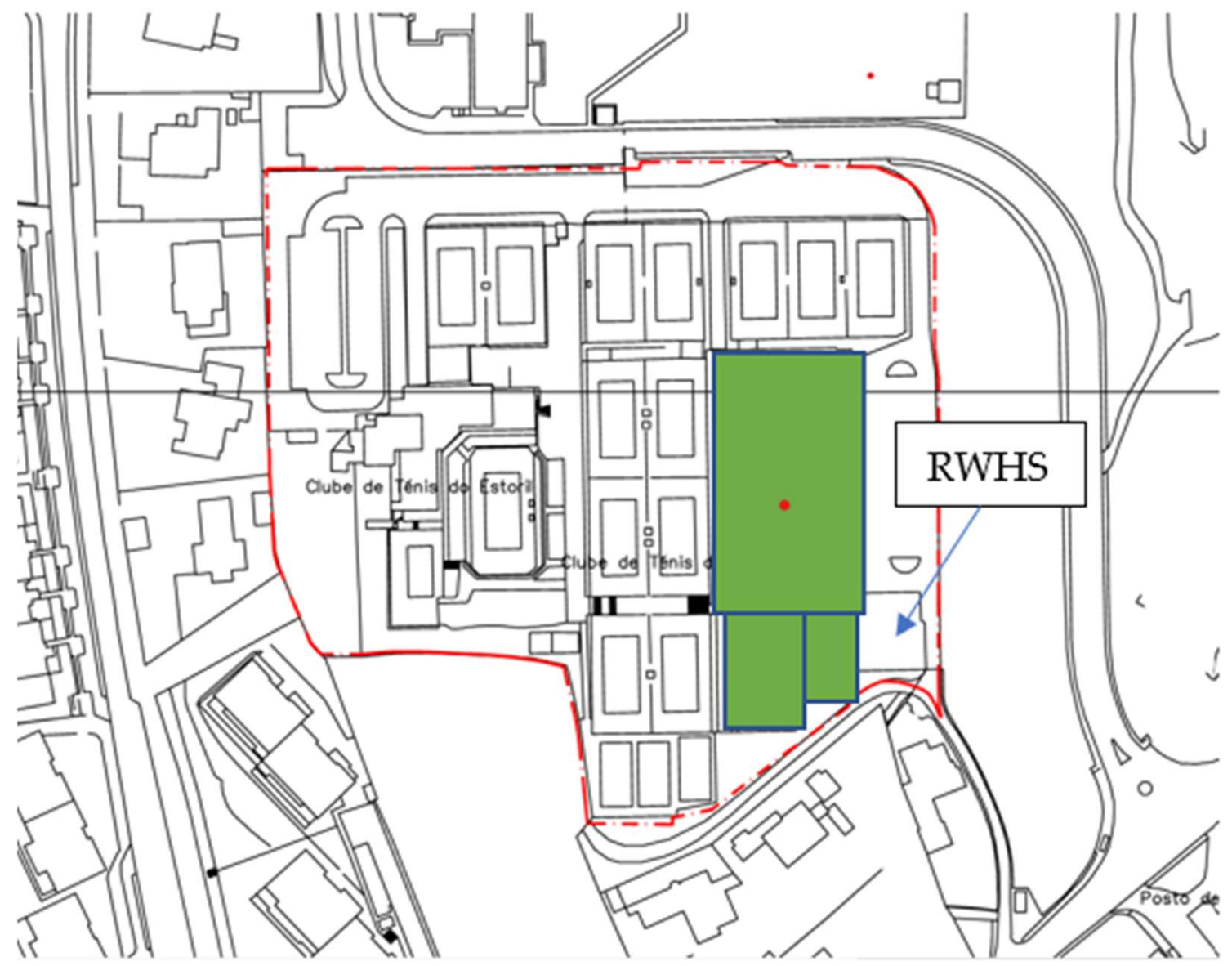

Figure 2. The Estoril Tennis Club (ETC) plan with the location of the rainwater harvesting system (RWHS) covers and installation site.

\section{Materials and Methods}

\subsection{General Aspects}

The ETC is internationally known as the headquarters of the 'Estoril Open', a professional men's tennis tournament belonging to the Association of Tennis Professionals (ATP) circuit. The ETC has 12 operational tennis courts in brick dust (six more that are not in use), eight of which are uncovered and four of which are covered with a metallic roof (Figures 1 and 2). It also has four covered paddle courts.

It should be noted that in brick dust fields, as in this case, the watering needs are much higher than those for other types of fields. In fact, brick dust fields need to be swiped with a net every hour and to be watered systematically to keep the playing surface aggregated and to prevent the dust from drying out completely. Upon drying, the dust becomes lighter and is removed by the wind.

In the case of the ETC, the annual water consumed in the fields is, on average, $5500 \mathrm{~m}^{3}$; it is supplied by the local public network. The local water authority is responsible for the metring and periodically communicates the consumption values (on the invoices) to the ETC, but it should be noted that the measurement periods are variable. This situation does not allow the invoice values to be used in this analysis, but the water authority performs an annual consumption adjustment, which makes the annual amount accurate. The value of $5500 \mathrm{~m}^{3}$ has had little variation in recent years, which is why it was considered adequate as a basis for this study.

The installation of an RWHS allows, in addition to significant savings in operating costs for the ETC, a more sustainable use of drinking water; it can also provide awareness for citizens and companies regarding the implementation of this type of sustainability measure in urban areas. This study was based on the European Standard EN 16941-1 [28] and the 
Technical Specification ETA 0701 [29] adopted in Portugal for the design, dimensioning, construction, and maintenance of these systems.

\subsection{Rainwater Availability}

The ETC has two large covers that are permanently closed (in green in Figures 1 and 2), whose use was considered in this study: a cover for four tennis courts and a smaller, more recent cover for the paddle tennis courts (four courts). These covers are arched roofs of metal plate, which discharge rainwater in trapezoidal side gutters, presently connected to the public stormwater drainage system outside of the facility through a network of pipes.

The tennis court cover has an area of $3500 \mathrm{~m}^{2}$, and the paddle court cover has an area of approximately $1400 \mathrm{~m}^{2}$, which totals an area of $4900 \mathrm{~m}^{2}$. The harvesting of this rainwater in a single place can be done without great complexity and can take advantage of the existing gutters, downpipes and drains in the covers.

For the development of this study, it was necessary to know the average monthly rainfall in the region. Data from the nearest meteorological station (S. Julião do Tojal) were used, accessible on the website of the National Water Resources Information System (SNIRH; apambiente.pt). Monthly data were used because (1) the official data available in Portugal are only monthly or annual and (2) ETA 0701, used in Portugal for the design of RWHS, recommends the use of monthly timesteps in sizing the cisterns. Hence, monthly timesteps were considered appropriate in this case study.

Regardless of the reasons mentioned that led to the choice of monthly timesteps, it should be noted that these timesteps have been used commonly in prior research [22,27,30-33] and that EN 16941-1 refers to the use of daily or annual time steps in the dimensioning of tanks, depending on the characteristics of the rainwater demand, the desired detail in the dimensioning of the tank, etc., while not also rejecting the use of monthly timesteps.

Based on the values provided by the SNIRH website, Table 1 was constructed and organised according to the hydrological year (beginning in October). The data in this table indicate that the total availability on average is $713 \mathrm{~mm} /$ year, which corresponds to $0.713 \mathrm{~m}^{3} /\left(\mathrm{m}^{2} \times\right.$ year $)$. For a total roof area of $4900 \mathrm{~m}^{2}$, this value corresponds to a total rainwater volume of:

$$
\text { Total availability }=4900 \times 0.713 \approx 3500 \mathrm{~m}^{3} / \text { year. }
$$

Table 1. Average monthly rainfall in Estoril (from the SNIRH website).

\begin{tabular}{cc}
\hline Month & Average Monthly Precipitation $(\mathbf{m m})$ or $\left(\mathbf{L} / \mathbf{m}^{2}\right)$ \\
\hline October & 75 \\
November & 106 \\
December & 105 \\
January & 103 \\
February & 93 \\
March & 77 \\
April & 56 \\
May & 45 \\
June & 16 \\
July & 3 \\
August & 5 \\
September & 29 \\
\hline TOTAL & 713 \\
\hline
\end{tabular}

This value would be affected by coefficients related to the efficiency of the filters and the runoff coefficient in the roofs, as mentioned later, so the useful value is $2830 \mathrm{~m}^{3}$. Recalling that the needs are around $5500 \mathrm{~m}^{3} /$ year, it can be noted that, at this stage (the ETC intends to carry out other coverage later and, in a second stage, increase the harvesting of rainwater), it will be possible to satisfy approximately $52 \%$ of the requirements for watering. In any case, in Mediterranean climates that are characterised by long droughts during the 
hot season ( $\geq 3$ months), it is generally not viable to supply all watering needs with an RWHS, as this would require large-volume cisterns and long retention periods, which are not feasible from technical, economic, and sanitary points of view.

\subsection{Storage Tank Characteristics and Volume}

In terms of investment, the storage cistern constitutes the main component of an RWHS. It is known that for large volumes, concrete cisterns that are built in situ are more economical than prefabricated cisterns. Nonetheless, the ETC opted for prefabricated high-density polyethylene (HDPE) cisterns that are easy to install, to avoid the disturbances necessary for the construction of a large concrete cistern that would impact the normal operation of this sports facility.

The sizing of rainwater cisterns is generally done based on the same methods traditionally used for sizing water reservoirs; it is based on supply-consumption differences during reference periods (daily or monthly), such as by the Rippl method [29]. In the present case, however, where the amount of rainwater is insufficient for almost every month, complex optimisation methods are not justified, and simplified methods can be adopted, according to ETA 0701. This specification is based, for example, on intended maximum retention periods. A volume corresponding to about 2 weeks of watering at the average annual flow was considered for the cistern, which led to the installation of two prefabricated $52 \mathrm{~m}^{3}$ cisterns. The total volume was $104 \mathrm{~m}^{3}$, which is compatible with the space available for this purpose, located next to the paddle area (Figure 2).

\section{Results and Discussion}

As mentioned above, the complex has 12 operational tennis courts in brick dust, eight of which are uncovered and four of which are covered with a metallic roof. The estimated average annual consumption for the irrigation of the fields is $5500 \mathrm{~m}^{3}\left(\approx 460 \mathrm{~m}^{3} / \mathrm{month}\right.$, on average).

To estimate monthly needs, days with precipitation were discounted in the fields that are not covered, as shown in the graph in Figure 3; data were also obtained from the SNIRH website. Thus, a weighting was carried out that considered the number of fields not covered and the days without precipitation $(D W P)$, which led to the values shown in Table 2.

Average number of days with precipitation in the Lisbon region $(R D)$ $(D W P=30-R D)$

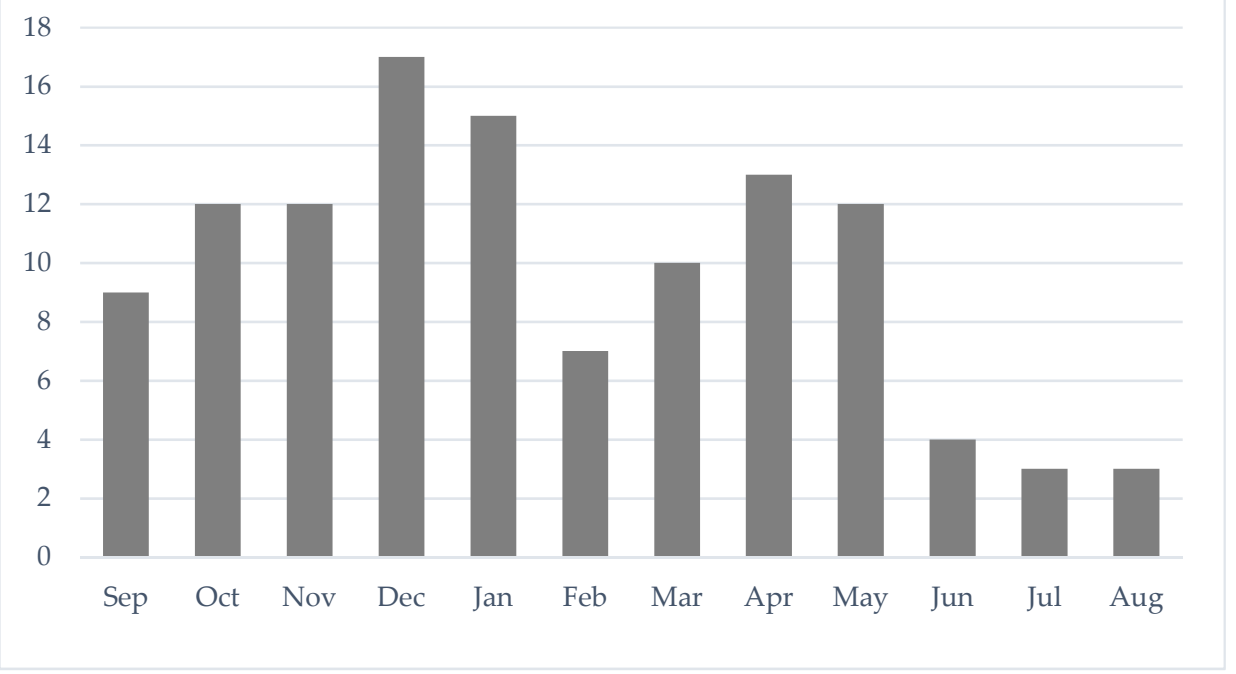

Figure 3. Rainfall days $(R D)$ in the Lisbon region. 
Table 2. Monthly consumption for irrigation estimated for an average year.

\begin{tabular}{|c|c|c|c|c|}
\hline Month & $\begin{array}{l}\text { Rainfall } \\
\text { Days }\end{array}$ & $\begin{array}{c}\text { Days without } \\
\text { Precipitation }\left(D W P_{M}\right)\end{array}$ & $\begin{array}{c}\text { Weighting } \\
\text { Factor }\left(W F_{M}\right)\end{array}$ & $\begin{array}{l}\text { Required Watering } \\
\text { Volume }\left(W V_{M}\right)\left(\mathrm{m}^{3}\right)\end{array}$ \\
\hline October & 12 & 19 & 9.07 & 437.05 \\
\hline November & 12 & 18 & 8.80 & 424.04 \\
\hline December & 17 & 14 & 7.73 & 372.48 \\
\hline January & 15 & 16 & 8.27 & 398.50 \\
\hline February & 7 & 21 & 9.60 & 462.59 \\
\hline March & 10 & 21 & 9.60 & 462.59 \\
\hline April & 13 & 17 & 8.53 & 411.03 \\
\hline May & 12 & 19 & 9.07 & 437.05 \\
\hline June & 4 & 26 & 10.93 & 526.68 \\
\hline July & 3 & 28 & 11.47 & 552.70 \\
\hline August & 3 & 28 & 1.47 & 552.70 \\
\hline September & 9 & 21 & 9.60 & 462.59 \\
\hline TOTAL & - & - & 114.14 & 5500.00 \\
\hline
\end{tabular}

In the construction of Table 2, the weighting factor for the month $M\left(W F_{M}\right)$ and monthly watering volume needed $\left(W V_{M}\right)$ were determined by the following formulae (where $N_{M}$ is the number of days in month $M$ ):

$$
W F_{M}=\left[4+8 \times\left(D W P_{M} / N_{M}\right)\right]
$$

and

$$
W V_{M}=W F_{M} \times\left(5500 / \sum W F_{M}\right)\left(\mathrm{m}^{3} / \text { month }\right) .
$$

A question that can be raised in relation to the values in Table 2 regards the possibility that they will be different in the future as a result of climate change. In fact, an increase in periods without precipitation is expected for Portugal in the short/medium term, among other consequences of climate change, which may imply an increase in the values for irrigation shown in Table 2. This effect, however, does not invalidate the present study, as it will mainly be reflected in an increase in the payback period, which, as will be seen, is relatively low for the current values. It should also be noted that the ETC intends to cover other fields in the future and to increase the use of rainwater, as mentioned above, so the situation will have further adjustments and optimisation over time.

According to ETA 0701, the volume of usable rainwater in a given period of can be determined by the expression:

$$
V a=C \times P \times A \times \eta_{f}
$$

where $\mathrm{Va}$ corresponds to the volume of rainwater in the reference period that can be used (litres), $C$ is the runoff coefficient (dimensionless), $P$ refers to the average precipitation accumulated at the site in the reference period $(\mathrm{mm}), A$ is the catchment area measured in horizontal projection $\left(\mathrm{m}^{2}\right)$, and $\eta_{f}$ (dimensionless) considers the hydraulic filtering efficiency. In the present case, $P=713 \mathrm{~mm}$ and $A=4900 \mathrm{~m}^{2}$, as previously mentioned. The value of 0.9 can be adopted for both $C$ and $\eta_{f}$, according to ETA 0701 .

In the simulation shown in Table 3, an initial volume of the cistern of approximately one third of its total volume was assumed, but it should be noted that a lower value has no influence on the results, as can be easily seen.

ETA 0701 imposes the use of upstream filters and recommends checking, in each case, the interest in diverting the first flush. The need to divert the first flush must be weighted according to the environmental pollution at the site (for example, roofs in low-polluted urban areas may eliminate the first flush diversion, but roofs in industrial areas with a large amount of dust must have this diversion) and also with the intended uses (for example, the quality of rainwater for washing floors is less demanding than for use in washing machines). In the present case, an upstream filter for leaves was foreseen, but the diversion 
of the first flush was considered unnecessary, given the localisation of the ETC and the intended use for the water; this was deemed especially important in order not to reduce the available volume of water.

Table 3. Rainwater harvesting system cistern simulation.

\begin{tabular}{|c|c|c|c|c|c|c|c|c|c|}
\hline Month & $\begin{array}{c}\text { Monthly } \\
\text { Precipitation } \\
\text { (mm) }\end{array}$ & $C$ & $\eta_{f}$ & $\begin{array}{c}\text { Available } \\
\text { Rainwater } \\
\text { Volume } \\
\left(\mathrm{m}^{3}\right)\end{array}$ & $\begin{array}{c}\text { Monthly } \\
\text { Consumption } \\
\left(\mathrm{m}^{3}\right)\end{array}$ & $\begin{array}{c}\text { Availability- } \\
\text { Consumption } \\
\qquad\left(\mathrm{m}^{3}\right)\end{array}$ & $\begin{array}{l}\text { Cistern } \\
\text { Volume } \\
\left(\mathrm{m}^{3}\right)\end{array}$ & $\begin{array}{c}\text { Water } \\
\text { Volume at } \\
\text { the End of } \\
\text { the Month } \\
\left(\mathrm{m}^{3}\right)\end{array}$ & $\begin{array}{c}\text { Public } \\
\text { Network } \\
\text { Supply } \\
\left(\mathrm{m}^{3}\right)\end{array}$ \\
\hline October & 75 & 0.90 & 0.90 & 297.68 & 437.05 & -139.38 & & 0.00 & 139.38 \\
\hline November & 106 & 0.90 & 0.90 & 420.1 & 424.04 & -3.33 & & 0.00 & 3.33 \\
\hline December & 105 & 0.90 & 0.90 & 416.75 & 372.48 & 44.27 & & 44.27 & 0.00 \\
\hline January & 103 & 0.90 & 0.90 & 408.81 & 398.50 & 10.31 & & 54.58 & 0.00 \\
\hline February & 93 & 0.90 & 0.90 & 369.12 & 462.59 & -93.47 & & 0.00 & 38.89 \\
\hline March & 77 & 0.90 & 0.90 & 305.61 & 462.59 & -156.98 & $2 \times 52,000$ & 0.00 & 156.98 \\
\hline April & 56 & 0.90 & 0.90 & 222.26 & 411.03 & -188.77 & $=104,000$ & 0.00 & 188.77 \\
\hline May & 45 & 0.90 & 0.90 & 178.61 & 437.5 & -258.45 & & 0.00 & 258.45 \\
\hline June & 16 & 0.90 & 0.90 & 63.50 & 526.68 & -463.18 & & 0.00 & 463.18 \\
\hline July & 3 & 0.90 & 0.90 & 11.91 & 552.70 & -540.79 & & 0.00 & 540.79 \\
\hline August & 5 & 0.90 & 0.90 & 19.85 & 552.70 & -532.86 & & 0.00 & 532.86 \\
\hline September & 29 & 0.90 & 0.90 & 115.10 & 462.59 & -347.49 & & 0.00 & 347.49 \\
\hline TOTAL & 713 & & & 2829.91 & 5500.00 & & & & 2670.12 \\
\hline
\end{tabular}

The rainwater collection network was sized for the peak flow, in accordance with the Portuguese General Regulation, and corresponded to a rainfall time of $5 \mathrm{~min}$ and a return period of 5 years. The value obtained was:

$$
I=56.6 \mathrm{~mm} / \mathrm{h}=0.016 \mathrm{~L} /\left(\mathrm{s} \times \mathrm{m}^{2}\right) .
$$

The formula applied to determine the tip flow $Q$ (in L/s) was:

$$
Q=I\left(\sum C_{i} \times A_{i}\right)
$$

where $C_{i}$ is the weighted (dimensionless) runoff coefficient of the area $A_{i}\left(\mathrm{~m}^{2}\right)$, and $I$ is the intensity of precipitation. In this case, the regulatory value of 1.0 was adopted for the roof runoff coefficient. Thus, for a total coverage area of $4900 \mathrm{~m}^{2}$, the flow rate obtained was:

$$
Q=0.016 \times 1.0 \times 4900=78.4 \mathrm{~L} / \mathrm{s} .
$$

Although industrial filters up to $6000 \mathrm{~m}^{2}(\approx 100 \mathrm{~L} / \mathrm{s})$ are available on the market, it was considered preferable to install two commercial filters for flow rates of up to $50 \mathrm{~L} / \mathrm{s}$ that were upstream of each cistern.

Variable speed pumping groups were installed in the tanks and considered a flow rate of $1.15 \mathrm{~L} / \mathrm{s}\left(4.140 \mathrm{~m}^{3} / \mathrm{h}\right)$ for a head of about $400 \mathrm{kPa}$. The value of $1.15 \mathrm{~L} / \mathrm{s}$ was sufficient for the simultaneous operation of three irrigation hoses, in accordance with the Portuguese General Regulation, and the head was determined based on the existing terrain unevenness and on the residual pressure recommended in the taps and in the head losses in the pipes.

The pumping group was specific for this use and contained automatic switching to the drinking water network in case of a lack of water in the cistern, ensuring the necessary sanitary safety. The catchment inside the cistern was done through a flexible hose to keep the aspiration below the free surface (for better water quality).

The cisterns had an overflow with a siphon, allowing the excess water to be discharged. On the other hand, to promote periodic cleaning and maintenance activities, bottom discharges or another total emptying solution were installed. The possibility of access to the interior of the cisterns through the respective cover (DN 650) was also guaranteed. A system of valves upstream of the cistern was provided so that the system could be connected/disconnected in case of the detection of anomalies or for its maintenance. 
The investment in this RWHS was estimated at approximately $€ 105,000$, according to the budget summarised in Table 4 . Given that the price of water paid by the ETC is $€ 1.6 / \mathrm{m}^{3}$ (it should be noted that this is a low tariff that is applied by the water authority to institutions considered to be of public interest) and considering the average annual consumption of $5500 \mathrm{~m}^{3}$, the estimated payback period for this investment is 11.9 years. Considering that the average useful life of these installations is around 40 years [34], this payback period is very interesting from an economic point of view.

Table 4. Budget summary.

\begin{tabular}{lc}
\hline \multicolumn{1}{c}{ Components (Installed) } & Cost (€) \\
\hline -Drainage pipes and accessories, including utility access holes and the watering network & 15,000 \\
-Two 52,000 L prefabricated cisterns, complete, including accessories and connections & 70,000 \\
-Two pumping systems, complete, including a water power grid, with water management & 8000 \\
(from cistern or mains) & 12,000 \\
-Two industrial leaf filters (DN 300) & TOTAL $(€)$ \\
\hline
\end{tabular}

It was not the intention of this article to study the effect of this RWHS in reducing flood peaks in the area, as they do not represent a serious problem in the city of Cascais at the present, but this additional advantage will undoubtedly exist and will be relevant, as highlighted in several scientific publications on the effects of RWHS in urban environments [35-42].

\section{Conclusions}

Dealing with climate change is one of the major challenges facing mankind in the 21st century, especially in urban environments, where around two thirds of the world population will reside in 2050. In some parts of the world, such as the Mediterranean basin, where the likely effects of climate change will be prolonged droughts and extreme precipitation events, RWHS in buildings seem to be an adaptation measure of great interest in urban environments because they provide a simultaneous response to these two situations. Therefore, these solutions should be widely generalised, possibly through a mandate in some regions. RWHS can be considered not only for buildings, but also for other urban infrastructure with high water consumption.

In this article, the implementation of an RWHS in a large-scale sports infrastructure that is intended for the practice of tennis and located in the city of Cascais, Portugal, was studied. The ETC has two large covers with a total area of $4900 \mathrm{~m}^{2}$, and the average annual consumption of drinking water to water the tennis courts at this facility is $5500 \mathrm{~m}^{3}$. The RWHS reduces this consumption by $>50 \%$ because it provides about $2830 \mathrm{~m}^{3} /$ year, in addition to reducing flood peaks in the area. In economic terms, the study predicts a payback period of around 11.9 years, which is clearly shorter than the useful life of the installation and proves the viability of this solution. It should be noted that, considering the average per capita value in Portugal of $127 \mathrm{~L} /$ (inhabitant and day), that is $46 \mathrm{~m}^{3}$ / (inhabitant and year), the drinking water saved with this system $\left(2830 \mathrm{~m}^{3} /\right.$ year $)$ corresponds to the annual consumption of approximately 62 inhabitants.

RWHS could constitute a relevant solution for adaptation to climate change in urban environments. Not being an unprecedented solution in buildings or football stadiums, for example, its application could be extended to other urban infrastructure, although in each case it would be necessary to analyse its technical, economic, and environmental interest. The present case study contributes to this context, demonstrating that the application of an RWHS in a large urban sports infrastructure dedicated to tennis presents high feasibility from all points of view. 


\begin{abstract}
Author Contributions: The authors made similar contributions to the development of this article. Conceptualisation, A.S.-A.; methodology, A.S.-A. and C.P.-R.; validation, A.S.-A. and C.P.-R.; formal analysis, A.S.-A.; investigation, A.S.-A. and C.P.-R.; writing-original draft preparation, C.P.-R.; writing-review and editing, A.S.-A. and C.P.-R.; supervision, A.S.-A.; project administration, C.P.R.; funding acquisition, C.P.-R. All authors have read and agreed to the published version of the manuscript.
\end{abstract}

Funding: This research received no external funding.

Institutional Review Board Statement: Not applicable.

Informed Consent Statement: Not applicable.

Conflicts of Interest: The authors declare no conflict of interest.

\title{
References
}

1. United Nations. World Urbanization Prospects: The 2014 Revision (Highlights); United Nations—Department of Economic and Social Affairs: New York, NY, USA, 2014; ISBN 978-92-1-151517-6.

2. Chalmers, P. Climate Change. Implications for Buildings. Key Findings from the Intergovernmental Panel on Climate Change, Fifth Assessment Report; European Climate Foundation, Building Performance Institute Europe, Global Buildings Performance Network, World Business Council for Sustainable Development, University of Cambridge's Judge Business School, Institute for Sustainability Leadership; BPIE: Brussels, Belgium, 2014.

3. Wilk, J.; Wittgren, H. Adapting Water Management to Climate Change; Swedish Water House Policy Brief 2009, Nr. 7; SIWI: Stockholm, Sweden, 2009.

4. Haines, A.; Kovats, R.; Campbell-Lendrum, D.; Corvalan, C. Climate change and human health: Impacts, vulnerability and public health. Public Health 2006, 120, 585-596. [CrossRef] [PubMed]

5. Trenberth, K. Changes in precipitation with climate change. Clim. Res. 2011, 47, 123-138. [CrossRef]

6. AWWA. Climate Change and Water Resources: A Primer for Municipal Water Providers; AWWA Research Foundation, University Corporation for Atmospheric Research, American Water Works Association; 1P-5C-91120-05/06-NH; IWA Publishing: Denver, CO, USA, 2006.

7. Magadza, C. Climate change impacts and human settlements in Africa: Prospects for adaptation. Environ. Monit. Assess. 2000, 61, 193-205. [CrossRef]

8. World Health Organization. Summary and Policy Implications Vision 2013: The Resilience of Water Supply and Sanitation in the Face of Climate Change; WHO_Department for International Development: Geneva, Switzerland, 2009; ISBN 978-92-4-159842-2.

9. Giorgi, F.; Lionello, P. Climate change projections for the Mediterranean region. Glob. Planet. Chang. 2007, 63, 90-104. [CrossRef]

10. Pausas, J.G. Changes in fire and climate in the Eastern Iberian Peninsula (Mediterranean Basin). Clim. Chang. 2004, 63, 337-350. [CrossRef]

11. European Commission. COM 718 Communication from the Commission to the Council and the European Parliament on Thematic Strategy on the Urban Environment; Commission of the European Communities-SEC: Brussels, Belgium, 2006; p. 16.

12. Wilby, R. A review of climate change impacts on the built environment. Built Environ. J. 2007, 33, 31-45. [CrossRef]

13. The Climate Change Clearinghouse: A Resource about Drinking Water, Wastewater, and Water Reuse. Changes in Precipitation. Available online: http:/ / www.theclimatechangeclearinghouse.org/ClimateChangeImpacts/ChangesInPrecipitation/Pages/ default.aspx (accessed on 20 October 2014).

14. La Licata, I.; Colombo, L.; Francani, V.; Alberti, L. Hydrogeological study of the glacial—Fluvioglacial territory of grandate (Como, Italy) and stochastical modeling of groundwater rising. Appl. Sci. 2018, 8, 1456. [CrossRef]

15. Dean, J.; Sholley, M. Groundwater Basin Recovery in Urban Areas and Implications for Engineering Projects. Engineering Geology for Tomorrow's Cities; IAEG: Dublin, Ireland, 2006.

16. United Nations. Buildings and Climate Change: Summary for Decision-Makers; United Nations Environment Program: Paris, France, 2009; ISBN 987-92-807-3064-7.

17. UNEP. Technologies for Climate Change Mitigation: Building Sector; UNEP Risø Centre on Energy, Climate and Sustainable Development: Copenhagen, Denmark, 2012; ISBN 978-87-92806-57-7.

18. Pimentel-Rodrigues, C.; Silva-Afonso, A. Contributions of water-related building installations to urban strategies for mitigation and adaptation to the climate change. Appl. Sci. 2019, 9, 3575. [CrossRef]

19. Kasmin, H.; Stovin, V.R.; Hathway, E.A. Towards a generic rainfall-runoff model for green roofs. Water Sci. Technol. 2010, 62, 898-905. [CrossRef]

20. Sheng, L.; Mari, T.; Ariffin, A.; Hussein, H. Integrated sustainable roof design. Proc. Eng. 2011, 21, 846-852. [CrossRef]

21. Silva-Afonso, A.; Pimentel-Rodrigues, C.; Tadeu, A.; Almeida, R.; Simões, N. Rainwater harvesting in buildings with green roofs: Runoff coefficients. In Proceedings of the Anais do CIB W062 2016-Water Supply and Drainage for Buildings, Kosice, Slovakia, 29 August-1 September 2016

22. Monteiro, C.; Calheiros, C.; Pimentel-Rodrigues, C.; Silva-Afonso, A.; Castro, P. Contributions to the design of rainwater harvesting systems in buildings with green roofs in a Mediterranean climate. Water Sci. Technol. 2016, 73, 1842-1847. [CrossRef] 
23. Pimentel-Rodrigues, C.; Silva-Afonso, A. Adaptation measure to climate change. Integration of green roofs with rainwater harvesting systems. WSEAS Trans. Environ. Dev. 2018, 14, 53-61.

24. Jack, L.; Kelly, D. The development of a methodological approach for the use of UK climate change data for the design of rainwater drainage systems for buildings. In Proceedings of the International Symposium CIB W062 2011—Water Supply and Drainage for Buildings, Aveiro, Portugal, 25-28 September 2011.

25. Pimentel-Rodrigues, C.; Silva-Afonso, A.; Lima, M. Rainwater harvesting systems in buildings with green roofs: A study on runoff coefficients. In Proceedings of the Anais do CIB W062 2017-Water Supply and Drainage for Buildings, Haarlem, The Netherlands, 23-25 August 2017.

26. Ekström, M.; Fowler, H.; Kilsby, C.; Jones, P. New estimates of future changes in extreme rainfall across the UK using regional climate model integrations. 2. Future estimates and use in impact studies. J. Hydrol. 2005, 300, 234-251. [CrossRef]

27. Adamiak-Burszta, E.; Spychalski, P. Water savings and reduction of costs through the use of a dual water supply system in a sports facility. Sustain. Cities Soc. 2021, 66, 102620. [CrossRef]

28. EN 16941-1; On-Site Non-Potable Water Systems-Part 1: Systems for the Use of Rainwater. CEN: Brussels, Belgium, 2018.

29. Associação Nacional para a Qualidade nas Instalações Prediais. Technical Specification ETA 0701-Rainwater Harvesting Systems in Buildings (Version 9); ANQIP: Aveiro, Portugal, 2015. (In Portuguese)

30. Bocanegra-Martinez, A.; Ponce-Ortega, J.; Nápoles-Rivera, F.; Serna-González, M.; Castro-Montoya, A.J.; El-Halwagi, M.M. Optimal design of rainwater collecting systems for domestic use into a residential development. Resour. Conserv. Des. 2014, 84, 44-56. [CrossRef]

31. Norman, P.; Porporato, A. Sizing a rainwater harvesting cistern by minimizing costs. J. Hydrol. 2016, 541, 1340-1347.

32. Chiemeka, O.; Solyah, O.; Akintug, B. Optimal sizing of storage tanks in domestic rainwater harvesting systems: A linear programming approach. Resour. Conserv. Des. 2015, 104, 131-140.

33. Jafarzadeh, A.; Pourreza-Bilondi, M.; Aghahhani-Afshar, A.; Khashei-Siuki, A.; Yaghoobzadeh, M. Estimating the reliability of a rainwater catchment system using the output data of general circulation models for the future period. Theor. Appl. Climatol. 2019, 137, 1975-1986. [CrossRef]

34. Hajani, E.; Rahman, A. Reliability and cost analysis of a rainwater harvesting system in peri-urban regions of greater Sydney, Australia. Water 2014, 6, 945-960. [CrossRef]

35. Freni, G.; Liuzzo, L. Effectiveness of rainwater harvesting systems for flood reduction in residential urban areas. Water 2019, 11, 1839. [CrossRef]

36. Akter, A.; Tanim, A.; Islam, M. Possibilities of urban flood reduction through distributed-scale rainwater harvesting. Water Sci. Eng. 2020, 13, 95-105. [CrossRef]

37. Campisano, A.; Modica, S. Rainwater harvesting as source control option to reduce roof runoff peaks to downstream drainage systems. Hydroinformatics 2016, 18, 23-32. [CrossRef]

38. Palla, A.; Gnecco, I.; La Barbera, P. The impact of domestic rainwater harvesting systems in storm water runoff mitigation at the urban block scale. Environ. Manag. 2017, 15, 297-305. [CrossRef] [PubMed]

39. Campisano, A.; Di-Liberto, D.; Modica, S. Potential for peak flow reduction by rainwater harvesting tanks. In Proceedings of the 16th Conference on Water Distribution System Analysis, Bari, Italy, 14-17 July 2014.

40. Campisano, A.; Butler, D.; Ward, S.; Burns, M.J.; Friedler, E.; DeBusk, K.; Fisher-Jeffes, L.N.; Ghisi, E.; Rahman, A.; Furumai, H.; et al. Urban rainwater harvesting systems: Research, implementation and future perspectives. Water Res. 2017, 115, 195-209. [CrossRef] [PubMed]

41. Behzadian, K.; Kapelan, Z.; Mousavi, S.J.; Alani, A. Can smart rainwater harvesting schemes result in the improved performance of integrated urban water systems? Environ. Sci. Pollut. Res. Int. 2018, 25, 19271-19282. [CrossRef] [PubMed]

42. Gado, T.; El-Agha, E. Feasibility of rainwater harvesting for sustainable water management in urban areas of Egypt. Environ. Sci. Pollut. Res. Int. 2020, 27, 32304-32317. [CrossRef] 